\title{
A SYMPOSIUM ON THE LAND TITLES ACT
}

\author{
The Law Society of Alberta Meeting, Calgary, \\ Alberta, January 5th, 1955.
}

The panel consisted of the following:

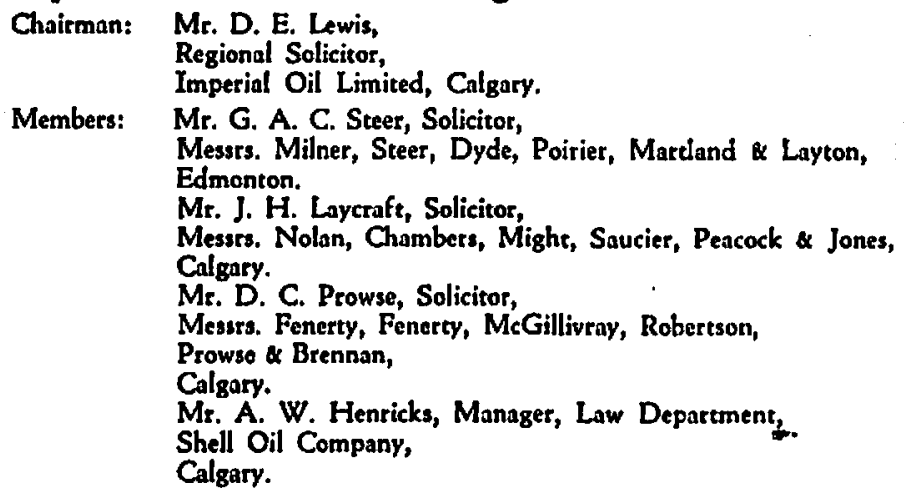

ThB Chatrman: The purpose of the Panel is to review the law relating to the method of registering mineral titles in the Province of Alberta and its effect. We intend to analyze the advantages and disadvantages of the present system. We submit that in order that a more satisfactory system of registration may be evolved, the present weaknesses must be alleviated.

The Benchers of our Law Society have been requested by the Premier of the province to make recommendations for changes in the present act which in their opinion, if adopted, would strengthen the Torrens System pertaining to the registration of mineral titles. This could take the form of a separate registration system based either on the Torrens System or the Registry System or a combination of both.

It is not our intention to make any specific recommendations for amendments or changes as a Panel, but we intend to open the subject and give our individual ideas on the problem and its solution so that further consideration may be given at this meeting to the problems raised and so that your conclusions may be of use to the Benchers in compiling their brief for the government.

There are, as you are aware, two modern systems in use in the Dominion of Canada under which land is registered. First, the registration of deeds system or the "Registry System," which is in effect in many parts of Eastern Canada. It provides a place or places wherein all documents relating to land can be registered and examined. In essence, this system may be summed up by stating that every person dealing with land is deemed to have notice of every document which is registered in the registry office and consequently is aware of the legal effect of that document. Awareness of an unregistered document is also considered in most jurisdictions to be actual notice. 
A person dealing with land must go to considerable trouble to discover the state of the title and to determine whether or not his predecessor in title is capable of passing a clear title. Unless a statute in the jurisdiction using the system shortens the period, such as in Ontario where the period during which a search has to be made is shortened to 40 years, every document from the original grant must be examined and interpreted. Because of the mechanies of searching, a solicitor works backward, starting with the original document and going back to the original grant or the statutory limitation. The reason for this is that the documents are registered under names in most instances and not by land description. Another registry or index book contains the encumbrances (mortgages, releases, etc.), so that it is a very lengthy and difficult job to search land.

The other system with which we are familiar, the Torrens System, tries to correct the cumbersome method of searching and to add certainty to the title. It is upon this system that the Alberta Land Titles Act is based. Land is registered by description and all documents affecting the land in a given area are registered in a central Land Titles Office. Upon registration of a document, the Registrar statesiits legal effect by the issuance of a Certificate of Title which the state warrants to be valid. Thus, any purchaser, in theory, needs only to ascertain that the person with whom he deals is the holder of a current Certificate of Title of land.

In practise, however, the draftsman of a Torrens statute must recognize that, despite the other precautions, mistakes will occur and that in some cases either a purchaser will not get a title for which he has paid or alternatively that a creation of a title for a bona fide purchaser will deprive the owner of his interest. Thus, there must be balanced the competing claims of the purchaser who desires a speedy and economical system of ascertaining title and of the landowner who desires that any title obtained will be secure against loss.

The system was devised in this province during a period when, with very few exceptions, surface lands were the principal interest and this system has operated most successfully. Since the discovery by Imperial Oil Limited of oil near Leduc in 1947, the value of the minerals has in a great many instances greatly exceeded the value of the surface. Everyone is now aware of the vital distinction between surface lands, and mines and minerals. This has led to careful scrutiny of existing titles, particularly when passing mineral lands. The weaknesses of foisting a system pertaining primarily to surface upon minerals have emerged. A minor criticism has also been made of the method the Crown uses in holding and registering mineral interests in lands which are the property of the Crown.

The object before this Panel is to examine the present land holding acts and systems of freehold and Crown land registration, keeping in mind the primary features of the indefeasibility under the Torrens System and its defects. 


\section{CONCLUSIVENESS OF THE CERTIFICATE OF TITLE}

Putting aside section 61 of the Land Titles Act, there are three exceptions to indefeasibility in the Act as it exists at the present time.

These are fraud, misdescription, and prior Cerrificate of Title. Of these exceptions the only one which had been exhaustively considered prior to the Turta case was fraud. That exception needs no discussion here.

The other two exceptions were directly raised by the Turfa case and perhaps before considering them it would be helpful to review the facts of that case in a very condensed form.

In the year 1903, Canadian Pacific Railway Company acquired a Certificate of Title to the north west quarter of 17-50-26 West of the 4th, inclusive of mines and minerals.

In 1908, Canadian Pacific transferred this quarter section to Mike Podgorny, reserving to itslf "all coal and petroleum".

The Registrar, in error however, issued a Certificate to Podgorny which reserved only coal to the C.P.R. In addition to this he reelled the C.P.R.'s Certificate of Title in full.

Under these circumstances there was no doubt that Canadian Pacific could have recovered the petroleum from Podgorny.

The situation, however, did not remain unaltered. Turta, through a number of transfers, in none of which any reservation of petroleum appeared, ultimately acquired title to the whole quarter section. The only reservation in his title was coal. Because Canadian Pacific's title was cancelled in full, Turta's title was the only title in existence for the petroleum.

In 1943, the Registrar corrected the chain of title by adding a reservation of petroleum. He also corrected the original C.P.R. title by adding to the memorandum of cancellation the words, "Ex. Coal and Pet.".

The jurisdiction of the Registrar to make these corrections need not be considered here except to say that his acts were ultra vires. The real problem is what interest Turta had acquired in the mincrals.

The answer depended on an interpretation of sections 62, 159 and 171 (e) and (f) of the present Land Titles Act. The effect of these sections in summary form is as follows:

Section 62 of the Act provides that a Certificate of Title is conclusive evidence that the person named therein is entitled to the land except in three cases. These are: fraud, "except as to any portion of the land included in the Certificate of Title by wrong description of boundaries or parcels"; and "except as against any person claiming under a prior Certificate of $T$ itle to the same land".

By section 159, it is provided that no bona fide purchaser shall be deprived of land of which he is registered as owner on the plea that his transferor was registered as owner through fraud or error, except in the case of misdescription as mentioned in section 157. To be bona fide within the meaning of section 
159, the purchaser must satisfy the terms of section 189 of the Act; that is, he must not be fraudulent, but he is not bound to enquire into the circumstances in which the land was acquired by his transferor. Nor is knowledge of an outstanding, unregistered interest considered as fraud under the Act.

Section 171 provides that no action to recover land shall lie against an owner except in specific cases. Two of these, namely subparagraphs (e) and (f), are important enough to justify a direct quotation of their material terms.

These deal with misdescription and prior certificate:

(e) The case of a person deprived of or claiming any land included in any . . . Cestificate of Titie to other land by misdescription of the other land or of its boundaries as against the ownec of the other land.

(f) The case of an owner claiming under an instrument of title prior in date of registration under this Act ... . in any case in which two or more grants or two or more certificatse of title are registered under this Act . . . in respect of the same land.

These sections show that if what had occurred in the Turta case was misdescription or prior certificate of ritle, Turta would lose.

The Court dealt with both these exceptions to conclusiveness of the Certificate of Title.

Insofar as misdescription was concerned, Mr. Justice Rand was prepared to say that it was not the Registrar's function to describe land but merely to transcribe what appeared on the transfer submitted to him for registration. As a consequence Mr. Justice Rand held that the Registrar could not misdescribe land.

He also, however, agreed with the other five judges who composed the majority in their conclusions as to what constitutes misdescription. The conclusion reached by the learned judges was that for there to be misdescription there must be a Certificate of Title for a patcel of land and included in that Certificate, there must be other land owned by another person. The best example of how a case of misdescription might occur is given by Mr. Justice Kellock, who said:

An owner of land making application to bring it under the Land Titles Act might include in the description of the land, other land belonging to another person which had not been brought under the Stotute. On receiving a certificate of title for his own as well as such other land, such cerrificate holder would be in a position to deal with it in favor of others, thus depriving the eriginal owner of the land by misdescription.

The explanation is obviously founded on a reading of section 171 (e) of the Land Titles Act. When, however, we attempt to carry this definition or explanation into the Act itself it is necssary to visualize two parcels of land owned by two individuals A and B and in two separate titles. A transfers his land and in so doing misdescribes it so that his transferee gets not only A's land but a part of B's land also. But it seems obvious that the chances of the Registrar's cancelling B's Certificate of Title are most remote since he has not in his hands a transfer referable to B's Certificate of Title. Such a situation would, therefore, apparently result in a case of prior certificate of title and it would appear that misdescription was intended to apply only to a case such as that given in the example by Mr. Justice Kellock, and that it was incorporated into the statute to protect owners of unregistered land. 
It seems to be impossible to go further than as indicated above in attempting to define misdescription. In any event it is now settled that misdescription does not include an error by the Registrar in carrying out his mandate as set out in the transfer by the transferor.

Turning to the second problem, that is prior certificate, the majority decision was that this was not a case of prior certificate. The decision rests on the simple fact that Canadian Pacific's title was cancelled on the register.

In so holding, the majority of the Court rejected an argument that in law a title could not be considered as cancelled unless it was cancelled in accordance with the provisions of the Act.

The reasons for judgment do not go into the question of prior certificate beyond this point. They do not say when an existing certificate of title will defeat another title.

Obviously the exception of prior certificate of title applies to a case where there are two grants from the Crown, both of which are registered (for the same parcel of land).

It seems that it also obviously applies where $A$ sells his land to $B$ and then to $C$ and both $B$ and $C$ get registered and commence two chains of title.

The only situation in which there might be some doube is the one where there is only a single chain of title. For example, if in the Turta case, the original C.P.R. title had not in fact been cancelled in full, would it have been a prior certificate of title which would prevail over the interest of Turta, who was a bona fide purchaser for value? The doubt is raised by section 159 of the Act, which makes no mention of prior certificate. That section says:

Nothing contained in this Act shall be so interpreted as to leave subject to action of ojectment any bond fide purchaser on the ground that his transferor has boen registered as owner through fraud or error. ...

The section makes no mention of prior Certificate of Title, and this was one of the grounds upon which Egbert $\mathrm{J.}^{2}$ held that the title of Canadian Pacific was not a prior Certificate of Title in this case. The same reasoning was applied by. Parlee J.A.

The question is, however, left undecided.

The Chalrman: Mr. Steer emphasized protection being given the purchaser. A person is only a purchaser for a very short period of time. Mr. Laycraft, in what way has the position of the owner been protected?

\section{THE ASSURANCE FUND}

A comprchensive system of title assurance is a fundamental part of the Torrens System. The English land system supported the title owner against all comers and before a purchaser acquired title he had numerous equitable obstacles to overcome. The purchaser is, however, more of a darling of the Torrens System than he ever was of Equity in that he acquires an indefeasible. title even though he has notice of conflicting interests. 
If a land system is to disregard the experience of centuries of equitable rules, it must provide a compensation for the hard cases against which Equity would have relieved before the statutory systems were introduced. It is interesting to note that a committee of the House of Lords, reporting in 1850 on reforms in the land law, stated that any scheme must involve either state insurance or private insurance for land owners and purchasers who lost the protection of the equitable rules.

Similarly the textbook writers recognize the assurance fund as an essential of the system. In Hogg's Australian Torrens System' the two essentials of the system are stated as:

(a) A warranty by the State of an indefeasible title in favour of a person registered as the owner of an interest in land.

(b) The creation of an assurance fund from the contribution of registered proprietors to answer any loss occasioned by wrongful registrations.

An examination of the assurance fund provisions of half a dozen of the leading Torrens statutes clearly shows the common origin of these sections. In the Alberta statute, section 157 creates the right of action against the assurance fund. Its language is virtually identical with section 186 of the New Zealand Act, and quite closely resembles section 246 of the Victoria Act. The typical provision provides for compensation to:

(1) A person who sustains loss or damage through omission, mistake or misfeasance of the Registrar,

(2) A person deprived of land through bringing it under the Act,

(3) A person deprived of land through registration of another as owner by error, omission or misdescription in a certificate of title, and who is barred from bringing an action for recovery of-land.

The analogy to an insurance policy should not be carried too far, however. Except in the case of the Registrat's error, the fund is liable only as a last resort. If there is another defendant who is also liable, he must be attacked and judgment will be given against the Registrar only if the judgment against the co-defendant is not satisfied.

The right to recover from the fund accrues only when an action has been brought against the Registrar and judgment has been obtained. Thus, however generous the assurance fund provisions are, they are completely dependent upon the limitation of the time within which an action may be brought.

Prior to 1949 , the limitation period where the action related to an error, omission or misdescription was six years from the time when it was first discovered. In 1949, however, the legislature saw fit to change the word "discovered" to "made". This slight change of wording made a drastic change in the limitation. If your title to mines and minerals was cancelled in 1930 and you discovered it only in 1950 the remedy was gone when the discovery was made. Previously time would have started running only in 1950.

Moreover, the Alberta limitation provisions contain a trap within themselves, since notice must be given to the Attorney-General three months before an action is commenced. Thus, if concrete steps have not been taken towards a supreme court action within a period of five years and nine months after an 
error, omission or misdescription has been discovered, the right will be forever lost.

It seems clear that the 1949 changes were intended by the legislature to protect the assurance fund from mines and minerals claims. The 1949 session of the legislature saw numerous fundamental changes to the law relating to mines and minerals. In addition to the changes to the Land Titles Act, the Mines and Minerals Act and the Public Lands Act were passed and substantial changes were made in the Mineral Taxation Act.

While the amendment to the limitation provisions was intended to limit mines and minerals claims, there is no doubt that it restricted the limitations with respect to the surface owner at the same time. If the change in limitation periods virtually destroyed the Torrens System as it relates to mincs and minerals, it did the same thing to surface titles.

If the Registrar, by error, cancels the title to your house and it passes from the new registered owner to a bona fide purchaser you must discover the error within six years or you will have lost not only your house, but your claim to compensation. It is no answer to say that such an eventuality is unlikely. The assurance fund was intended to guard against just such unlikely events.

The highest hurdles placed before the mineral owner who has suffered loss by the workings of the Torren System are found in section 167A, which was added to the statute in 1949 and amended in 1953:

(1) A claimant recovers only the moneys actually paid for mines and minerals plus a maximum of $\$ 5,000$ for loss of profit.

(2) No person has an action arising out of the disposition of mines and minerals after March 29,1949, unless the Registrar has issued a mineral certificate.

The section directs the Registrar to search and examine the ownership of the interest in mines and minerals, and if it is found that the person purporting to make the disposition was the correct owner of them, his mincral certificate is issued.

In actual practice, the Registrar will not issue a mineral certificate unless the ownership of the parcel is plainly beyond doubt. Even if the error occurred before 1949, the holder of a lease dated after 1949 can recover nothing from the fund. Of course, by March 29, 1955, the six-year limitation period would preclude recovery for error before March, 1949, in any event.

Section 167A very effectively shields the fund against claims for old errors in the register. The section has excited the admiration of the Saskatchewan government and was copied into the statutes of that province in 1951 to restrict the remedies available to its mineral owners.

The mineral certificate should not be thought of as a certificate of title. In fact its principal effect is to certify that the holder of it has freed himself from the disability of not being able to sue the assurance fund at all, but can now sue for his "out-of-pocket" expenditures plus $\$ 5,000$ loss of profit.

It should not be assumed that the Alberta Land Titles Act is the one villain among all the "true-blue" Torrens Systems. The statutes of a number 
of other jurisdictions use the device of the limitation period to protect the assurance fund. Manitoba, Saskatchewan, British Columbia, Victoria and New Zealand, to mention only a few, limit the time within which an action may be brought to six years from the date of deprivation of land. Nor are full claims against the fund allowed in all jurisdictions. In Victoria the value of buildings and other improvements put on the land subsequent to deprivation is excluded or limited.

Indeed, the more generous limitation provisions have been in effect in Alberta during only a few years of our history. Prior to 1941, the limitation period in Alberta had always been six years from the date of deprivation. Writing in 1920, Mr. Hogg was able to say that the claimant's knowledge or lack of knowledge was immaterial in all important land titles acts.

In 1941 came the change that time would run only from the date that the claimant had knowledge of the error, omission or misdescription.

In all justice, therefore, I am bound to say that the 1949 change which I criticize so severely merely made Alberta's limitation provisions the same as those in virtually all other Torrens Systems.

During the enlightened years from 1941 to 1949, Alberta assurance fund provisions were probably the most generous to be found. Nevertheless, perhaps Alberta should not shrink from generosity.

The Chairman: Mr. Prowse, the discussion until now has considered the Cerlificate of Title of the purchaser as owner. As you are aware, dispositions of land take a number of forms other than the registration of a Transfer, such as mortgages, leases, easements and the like, which are protected by way of Caveat. In some instances, the legality of the Caveat may be questioned or it may be of no arail. Would you give us the benefit of your study on some of the problems raised by Careats?

\section{CAVEATS.}

As the scheme under the Torrens System of registration is to recognize only registered interests in land, and as the Act only provides for the registration of a few simple instruments which pass a registered estate or effect a registered charge on land, of necessity provision is made in the Act to permit a person claiming an interest in land to have a memorandum of his claim noted on the title to that land. Section 131 of the Land Titles Act permits a person claiming an interest "howsoever in any land" to register a Caveat. The registration of a Caveat serves two purposes: first, it serves as notice of the Caveator's claim to all persons dealing or proposing to deal with the owner of such land, and second, the time of registration prima facie determines the priority of the Caveator's claim in relating to competing claims against the same land. I have used the word "prima facie" as in some circumstances apparent priority can be displaced. I have in mind the provisions of section 189 of the Act.

I do not want to deal with Caveats generally but rather with one question that does arise when a Caveator assigns all of his right, title and interest in and 
to certain lands after he has protected that claim by the registration of a Caveat and thus established the priority of his claim.

Under section 131, any person claiming an interest in land may file a Caveat, and under section 136, the same person may withdraw his Caveat by giving written notice to the Registrar. Further, under section 137, any person claiming an interest in the land may serve a notice upon the Caveator requiring him to take proceedings to substantiate his claim. In the event that he does not take such proceedings within the time limited by the notice, then his Caveat will lapse. In view of these provisions, an assignee who files a Caveat relying on his assignor's Caveat for purposes of priority may find himself in a precarious position. Let us assume the following facts:

(1) $A$ is the registered owner in fee simple of a quarter-section of land.

(2) A grants a petroleum and natural gas lease to $B$.

(3) Thereafter A grants a second petroleum and natural gas lease to $C$.

(4) C, being more familiar with provisions of the Torrens System, files the first Caveat.

On these facts and in the absence of fraud, it follows from the sections of the Act dealing with priority that C's lease forms the first encumbrance against A's title.

If we now assume that $B$ files a Caveat and that thereafter $C$ assigns his lease to $D$, who files a Caveat, it follows that D's claim to priority over $B$ depends upon his right to claim the benefit of C's Caveat.

This question was considered in Gas Exploration Company of Alberla Limited and Lee v. Cugnet', where Mr. Justice Graham held:

I have had, therefore, to consider the position of an assignee of the lessce's interest in a petroleum and natural gas lease and the resultant position of a caveat registered by the original lessee and based on the said lease. I can find no authority dealing with this specific point but have reached the conclusion that the assignee, having been granted an assignment of all the interst of the assignor in and under the lease, would be entitled to rely on the righe of priority secured by the caveat registered by the assignor and that as a result the assignee is entitled to have the caveat continued. This reasoning and the conclusion I have renched would be equally applicable if the interst of the assignee is further assigned. To hold otherwise would, in $\mathrm{my}$ opinion, deny the effect of the filing and regisration of a caveat under the provisions of the Land Titles Act and of the Torrens System of land tenure.2

This is the only case I have found dealing with this point and there are no specific provisions in the Act covering the question. When one considers the number of leases that could be affected if this case were not followed in our province, the seriousness of the problem becomes apparent.

The question becomes more complicated if we assume that for some reason $C$ decides to withdraw his $C$ aveat, or if $C$, on receiving a notice to take proceedings to substantiate his claim, fails to advise $D$ and throws the notice in his waste paper basket because he is no longer interested in the land. In either case, the result may be that after C's Caveat had lapsed or had been withdrawn B's lease would become the first encumbrance and would find his priority lost even though he had no notice and consequently no opportunity to take steps to protect his interest.

It would appear that all D could do would be to hope that another court would extend the application of the "common sense" which formed the basis 
of Mr. Justice Graham's decision. The suggestions I make for your consideration are:

(1) That the Act be amended to give an assignee the benefit of his assignor's Caveat, and

(2) Until such amendment is made, that an assignee require his assignor to change the address for service on his Caveat so that the assignee will receive all notices ditected to his assignor under section 137 of the Act.

The Chairman: Thank you, Mr. Prowse. You have helped us in understanding the dangers inherent in Caveats. However, there are other exceptions statutory in form which may overrule the Land Titles Act and nullify or vilally affect the existing Certificate of Title. If you have considered any of these, would you give us the benefit of your deliberations?

\section{THE HIEBERT CASE}

The exception set out in section 61 (a) of the Land Titles Act, which reads as follows:

The land mentioned in any certificate of title shall be subject to:

(a) Any subsisting reservation or exception, including royalties, contained in the original grant from the Crown

must be considered in the light of the decision of the Supreme Court of Canada in Canadian Superior Oils of California and Hiebert v. The District Registrar of the Land Titles District of Porlage la Prairie', where the facts were as follows:

(1) The Province of Manitoba placed certain lands under the provisions of the Real Property Act ${ }^{2}$ and obtained a certificate of title in the name of His Majesty in the Right of the Province.

(2) The Crown then sold the land and executed a transfer in the form set out in the Real Property Act which purported to transfer to the purchaser "all our estate and interest in the said lands".

(3) Section 3 of the Real Property Act provided ". . . land shall extend to and include . . mines, minerals . . . unless such are specially excepted".

(4) Hiebert eventually became the registered owner in fee simple of the land as the bona fide purchaser of the same from a person who was also registered as owner in fee simple.

(5) Hiebert granted a petroleum and natural gas lease to Canadian Supcrior Oils.

(6) Canadian Superior Oils presented a Caveat for registration.

(7) The Registrar refused to accept the Caveat.

(8) Section 21 of the Provincial Lands Act provided that "no grant from the Crown of lands will operate as a conveyance of the gold or silver mines or any other mineral therein unless the same are expressly conveyed in such grant".

The Registrar and the Attorney-General for the Province of Manitoba took the position that by reason of section 21 of the Manitoba Provincial Lands Act 
the petroleum and natural gas did not pass from the Crown as the same were not expressly conveyed in the original grant from the Crown. Canadian Superior Oils took the position that in view of section 3 of the Real Property Act, as there were no express reservations in the original transfer from the Crown, the mines and minerals passed to the transferee and were not reserved by section 21 of the Manitoba Provincial Lands Act.

There are numerous conflicting judgments and I will not attempt to summarize them but will take the bold approach and submit that the effect of the case is:

(1) That a transfer by the Crown under the Land Titles Act is a grant.

(2) That the wording of grants from the Crown must be interpreted in the light of the definitions found in the particular Act under which the grants were made.

(3) That in case of conflict between the Public Lands Act and the Land Titles Act, the Public Lands Act will be paramount as it deals specifically with Crown land whereas the Land Titles Act deals with land generally.

In considering the extent of the exceptions set out in section 61 (a) of the Land Titles Act, it has been the practice to merely refer to the original grant from the Crown and interpret the wording of that grant in the light of the definitions found in the Land Titles Act. For instance, if X Oil Company wanted to take a petroleum and natural gas lease from " $A$ ", who was registered as owner in fee simple of a piece of land, and a search for the original grant from the Crown disclosed no exceptions on the face of it, we have in the past assumed that X Oil Company could rely on " $A$ 's" title. In view of this practice, I was asked to deal with this case, and I would submit that such a search is not sufficient and we must now go one step further and consider the provisions of the Act under which the original grane was made in order to interpret the wording of the grant.

It will be appreciated that this problem can also arise with respect to land grants made under Alberta's Public Lands Act. That Act provides that:

There is hereby reserved to the Crown our of every disposition of public lands under this Act .... (e) all mines and minerals.

By virtue of section 3 (1) of that Act, the same applies to all lands vested in the Crown in the right of the province.

The Chairman: Mr. Henricks, Mr. Prowse has dealt with the Hiebert case and similar situations. In the course of your work have you bad any dealings with another type of statutory conflict which should be considered in a panel of this sort?

\section{SECTION 198 OF THE RAILWAY ACT}

An additional problem encountered from time to time in dealing with freehold oil and gas rights is the one posed by section 198 of the Railway Act. ${ }^{2}$

The section reads as follows:

(1) The company is not, unless the sume have been expressly purchased, entitled to any mines, ores, metals, coal, slate, mineral oils, gas or other minerals in or under any lands 
purchased by it, or taken by it under any compulsory powers given it by this Act, except only such parts thereof as are necessary to be dug, carried away or used in the construction of the works.

(2) All such mines and minerals, except as afoxesaid, shall be deemed to be excepted from the conveyance of such lands, unless they have been expressly named therein and conveyed thereby.

For a simple statement of facts which will help to illustrate the problem, let us assume that Smith in 1915 was the owner of an estate in fee simple of and in the north west quarter of section 10. That year he sold to the railway company six acres for a right-of-way across his land. The transfer was simple, the description of the land was, of course, by reference to a surveyed plan, but there was no reservation or exception of any mines and minerals and the title for the six acres which issued to the railway company likewise contained no reservation or exception of mines and minerals.

The problem is, did the railway company acquire a good title to the minerals which it could pass on to others?

It is, I think, clear that the acquisition and ownership of land is a matter of property and civil rights under section 92 of the B.N.A. Act and thus is prima facie within the jurisdiction of the provincial legislatures. Applying the many and varied decisions of the courts to the factual situation, it can properly be said that the acquisition of land for railway construction and all the incidents of such acquisition are necessarily incidental to legislation by the Parlia. ment of Canada respecting railways and therefore a valid subject for legislation by Parliament.

Subsection 29 of section 91 of the B.N.A. Act is one of the items to which the exclusive legislative authority of the Parliament of Canada extends. The subsection reads:

Such Classes of Subjects as are expressly excepted in the Enumeration of the Classes of Subjects by this Act assigned exclusively to the Legislatures of the Province.

Subsection 10 of section 92 provides that the provincial legislatures have exclusive legislative power with respect to

Local Works and Undertakings other than such as are the following Classes:

(a) Lines of Steam or other Ships, Railways . . . connecting the Province with any other or others of the Provinces, or extending beyond the Limits of the Province.

\section{In Montreal v. Montreal Street Railway, Lord Atkinson said:}

Now the effect of sub-s. 10 of s. $92 \ldots$ is . . to transfer the excepred works mentioned in sub-heads (a), (b), and (c) of it ineo 3. 91, and thus to place them under the exclusive jurisdiction and control of the Dominion Parliament.

In A.G. for Canada v. A.G. for B.C. ${ }^{3}$ Lord Tomlin reviewed the authorities and then stated: ${ }^{4}$

It is within the competence of the Dominion Parliament to provide for matters which, though otherwise within the legislative competence of the provincial legislature, are necessarily incidental to effective legislation by the Partiament of the Dominion upon a subject of legislation expressly enumerated in s. 91 .

And so, of course, if this line of reasoning is followed the excepted works in section 92 are transferred into section 91 so as to become expressly enumerated therein and anything that can be considered necessarily incidental is within the competence of Parliament. 
There are other cases to which reference can be made for authority for the above proposition if you wish to support that contention. I might point out that in the two cases which I cited the Privy Council affirmed the earlier judgments of the Supreme Court of Canada.

There seems to be ample authority for the Parliament of Canada to have empowered the railway company to purchase minerals in excess of those necessary for the work involved, so that if the mineral rights under our quartersection had been "expressly purchased" it would have been within the competence of the railway.

But can it not be said with some force that these words "expressly purchased" are satisfied by the following provisions of section 8 of the Transfer and Descent of Land Act, ${ }^{5}$ which reads, in part, as follows:

No words of limitation shall be necessary in any transfer or conveyance of any land in order to transfer all or any title thercin, but every instrument transferring lond shall operate as an absolute surtender of all such right and title as the transferor has therein at the time of its execution, unless a contrary intention is expressed in the transfer or conveyance; but nothing herein contained shall preclude any transfer from operating by way of estoppel; . . .

There is more to the section but I do not believe that it is material to this discussion.

Consider also the pertinent sections of our Land Titles Act. I suggest that it would not be unreasonable to conclude that the words "expressly purchased" are met by these provisions.

Subsection 2, however, deals not with powers of the railway but with the form and effect of conveyances under our Land Titles Act and is, of course, in direct conflict with certain provisions of our statutes. It can be forcibly argued without in any way denying the right to legislate regarding the power to acquire lands, that this subsection cannot be supported as legislation incidental to railways and so within the power of the Parliament of Canada, at least to the extent that it conflicts with provincial legislation relating to transfers of land, otherwise clearly within the legislative competence of the provincial legislature. There are strong decisions to the effect that competent railway legislation does not go on forever nor can it cover limitless matters.

Assume for the moment that section 198 of the Railway Act is ultra vires of the Parliament of Canada, that "expressly purchased" is not satisfied as I suggested, and that, because the Registrat of Land Titles is presumed to know the law, he should have reserved the mines and minerals when Smith transferred the land to the railway. What is the position of a person who takes a lease of these rights from the railway relying on the register? The Turta decision, of course, strongly supports the position of a bona fide purchaser for value as against the claims of a person deprived of land by the Registrar's error. On the assumption mentioned above, the title of the railway is defeasible as it had no right to the minerals and if the intended lessee, relying on the information disclosed by the existing certificate of title, dealt with the railway it may be forcibly argued that he acquired a good leasehold title. Further, even if he knew of the defeasibility of the railway's title, in the absence of fraud, he would be protected by the provisions of section 189 which protects a bona fide purchaser, notice in itself not being fraud. 
The constitutional aspect of the problem can only be finally settled by the courts and I understand some activity in that regard is under way. If it transpires that the railway company, in my hypothetical situation, does not own the mineral rights, there is the problem of dealing effectively with mineral rights which for 30 years have been considered to be owned by the railway.

If it is not clear now, then it should be made clear that, under our Land Titles Act, the bona fide purchaser can acquirc a good title. Provision should be made for the party deprived of title through error.

The Chairman: It is my understanding that this problem will be taken before the Courts of Manitoba by way of reference in the fall of this year. It should be very interesting to follow the decisions in the case, as considerable land will be affected.

After listening to this discussion and noting the problems raised, what are your thoughts-as an oil company solicitor-on the need for and value of an historical search?

\section{HISTORICAL SEARCHES}

The business of drilling for oil and gas is very costly and very speculative. Notwithstanding some suggestions to thecontrary which from time to time appear in the press and over the air, none of us know really where or for whom the oil and gas were originally made. It costs a great deal to drill even a shallow hole and the reward for drilling varies from bankruptcy to financial bliss.

That being the case, the company, be it large or small, planning to drill requires assurance that the title to the tract proposed to drill will stand. That is where our interest in historical searches begins.

We consider historical searches absolutely necessary even though very expensive. Now I'm discussing historical searches as we know and do them. I'm sure that many of you have different and better ways, but we have found - . our way satisfactory for our purposes.

Let us start with freehold oil and gas rights. Upon receiving a request for title opinion with respect to a parcel of freehold rights, we begin a search at the Land Titles Office, starting, of course, with the original grant of land from the Crown, commonly referred to as the patent. If we find that in the patent there is a reservation of mines and minerals to the Crown, we normally assume that our freehold lessor of oil and gas rights may have been dealing with something not owned by him, but the mere fact that a lease was taken is quite enough to arouse our interest in the matter. Assume, however, that the original patent does not reserve mines and minerals to the Crown. We then work through the chain of title created by all the various dispositions of those rights following them to the present Certificate of Title. On the way you can encounter every conceivable instrument contemplated by the Land Titles Act. Some of these can be ignored, particularly where they do not involve any possibility of a change in interest of the rights being searched. 
I won't deal with the difficulties or problems that can be found in conducting an historical search. My colleagues on this panel have dealt with the more important ones. I wish to make only this further observation with respect to our experience in conducting historical searches of freehold oil and gas rights. We have done a great many of them and we have not encountered very many problems. However, those problems which have been encountered are of the serious and usually complicated variety discussed by my colleagues.

I turn, then, to historical searches of Crown mines and minerals. In the first place, it may seem to make little sense to conduct an historical search of lands owned by the Province of Alberta. I agree that if we could be sure that the province owned each parcel of land with which it purports to deal, our load would be much lighter. I would like to describe in a moment two classes of problems which are giving us much concern although, fortunately, not very frequently.

In our historical searches of Crown oil and gas rights, besides checking with the Department of Mines and Minerals, we also do what searching is possible at the particular Land Titles Office. In the case of most lands lying north of Edmonton, this doesn't require much work because a relatively small amount of this land has been settled. But in other parts of the province there will be, very often, a very long and sometimes complicated chain of title covering the surface from the original grant from the Crown down to the present certificate. Almost without exception when Crown lands are being considered, the original grants from the Crown will contain a reservation to the Crown of the mines and minerals. We nevertheless run an historical search on the surface in an effort to discover any possibility of the land's having been by error or otherwise dealt with as to mines and minerals on a Certificate of Title.

The two problems to which I referred a moment ago arise under the Natural Resources Act ${ }^{1}$ by which in 1930 the Province of Alberta acquired a tremendous amount of natural resources within the province. By making an historical search through the surface titles we can, for example, encounter this situation which will be hypothetical but, I assure you, an example of a real problem.

In 1910, Blackacre was granted by the federal Crown to Smith, reserving unto His Majesty all mines and minerals.

Following the First Great War, the Soldier Settlement Board in 1922 purchased the land from Smith on behalf of a soldier pursuant to the Soldier Settlement Act. ${ }^{2}$ A Certificate of Title was issued in the name of the Soldier Settlement Board, reserving, of course, unto His Majesty all mines and minerals.

In 1947 the provincial Crown granted a petroleum and natural gas lease to the Black Velvet Oil Company. In the following year, 1948, the Soldier Settlement Board transferred the land, reserving unto $H$ is Majesty all mines and minerals, to the soldier presumably on the strength of the soldier's having complied with the requirements of the Soldier Settlement Act.

No patent to the mines and minerals had ever been granted. 
On the face of it there does not seem to be any problem. At all times the mines and minerals were reserved to the Crown and, under the Natural Resources Act, it would seem to follow naturally that these mineral rights would pass to the Province of Alberta. Unfortunately, the views taken by the pro. vincial and federal governments are not the same. Section 13 of the Alberta Natural Resources Act provides that all interests in Crown lands in the province upon the security of which any advance had been made under the provisions of the Soldier Setticment Act, shall continue to be vested in and administered by the Government of Canada for the purpose of Canada. The federal Crown takes the position that money was advanced to purchase the surface of this land when the Soldier Settlement Board acquired it in 1922; but when the land was transferred to the Soldier Settlement Board, which is an instrument of the Crown, there was a merger of the surface and the mineral title and that the mineral title which had been reserved to the Crown originally was therefore cursed with the stigma of the advance made by the Soldier Settlement Board to the surface, with the result that the mineral rights did not pass to the Province of Alberta in 1930.

Now that problem arises under a system of Crown mineral rights registration established by sections 288 and 289 of the Mines and Minerals Act which says nothing whatsoever that would give any comfort. It is conceivable that under a registry or a Torrens System the mineral rights, regardless of who might own them, could be dealt with on the basis of an indefeasible title such as we normally consider attaches to lands held under the Torrens System.

The second problem which we have encountered arises also under the Natural Resources Transfer Act. Again we use a hypothetical case.

In 1910, Blackacre was granted by the federal Crown, to Smith, reserving unto His Majesty all mines and minerals. Smith's Certificate of Title, of course, reserved mines and minerals. In 1928, Smith transferred all his interest to His Majesty King George V in right of Dominion of Canada represented by the Superintendent General of Indian Affairs. Certificate of Title which issued in the name of His Majesty as aforesaid reserved unto His Majesty all mines and minerals. This land was purchased for grazing purposes for a certain band of Indians in the province. In 1950 the provincial Crown granted a petroleum and natural gas lease to the Black Velvet Oil Company. No patent to the mines and minerals has ever been granted.

Now the problem here is a litcle more complicated than in the case of the Soldier Settlement Board lands and I'm not going to discuss it at any length but I will refer you to section 10 of the Alberta Natural Resources Agreement. The section provides, in effect, that all lands included in Indian reserves shall continue to be vested in the Crown and administered by the Government of Canada for Canada. We then have to go to the Indian Act to try to determine whether these lands are properly included within the definition of reserves. Having done that, we are well on our way toward solution of the problem. Once again the views taken by the provincial and federal Crown respectively are at variance and so an adviser to the Black Velvet Oil Company 
is asked to climb aboard one of two horses and place his reputation as a legal practitioner on the line.

The fact that the problem is not of easy solution is, I think, evident by the fact that a group of surface owners in an Indian reservation between Calgary and Edmonton are presently taking action with respect to the mineral rights of their lands.

The question is, should all minerals, freehold and Crown, be under a separate system of registration such as the Torrens System?

The Chairman: The discussion so far has concerned itself with freehold land owners. As you are aware, approximately 86 per cent of the mineral land in Alberta is owned by the Crown in the right of the Province. Mr. Henricks, would you review briefly the method of holding and disposing of Crown lands? It must be kept in mind that, should a revision be made of the registration of mineral titles in the province, consideration will have to be given to the Crown lands and whether or not they should be included in such a system of registration.

\section{CROWN LANDS}

I would like to commence my discussion of this topic by describing very briefly the methods by which the Province of Alberta acquired its ownership of something like 86 per cent of the mines and minerals within the province.

At the time of the incorporation of the province in 1905, the Alberta Act ${ }^{2}$ provided:

All Crown lands, mines and minerals and royalties incident thereto ... shall continue to be vested in the Crown and administered by the Government of Canada for the purposes of Canada, subject to the provisions of any Act of the Parliament of Canada with respect to road allowanees and roads or trails in force immediately before the coming into force of this Act, which shall apply to the said province with the substitution therein of the said province for the Northwest Territories.

This provision seemed to make it abundantly clear that the province did not by the act of incorporation acquire very much in the way of land.

Another 1905 statute dealing with roads in Alberta and Saskatchewan ${ }^{2}$ provided for the vesting in the provincial government of existing or subsequently created road allowances and the Dominion lands comprised within them. The next year, however, the Dominion government passed another act ${ }^{2}$ which provided for the non-vesting in the provincial government of mines and minerals under any road or trail on Dominion lands.

Under a Northwest Territories ordinance the province was able to acquire the mineral rights in land expropriated for public works. Probably some small amount of mineral rights was acquired under that ordinance.

By the Land Titles Act, ${ }^{4}$ provision was made for the province's acquiring the lands within any road taken by the province as long as it was Dominion land and the entire interest was acquired. But in 1911 that particular section of the Land Titles Act was amended' by the addition of language to the effect that the Crown is not entitled to any mines or minerals, solid, liquid or gaseous, 
within, upon or under any lands vested in the Crown under this section unless they are expressly purchased.

Then we come to the Natural Resources Agreement dated December 14, 1929, which came into force on October 1, 1930, by which the interests of the federal Crown in all Crown lands, mines, minerals and royalties derived therefrom within the province and all sums due or payable for such lands, mines, minerals or royalties pass to the province subject to the terms of the agreement and to any trusts existing in respect of them and subject also to any interest other than that of the Crown in the same.

At the present time the mines and minerals owned by the Crown are administered by the Department of Mines and Minerals under the Mines and Minerals Act. ${ }^{7}$ I don't propose to deal at any length with the Mines and Minerals Act but I would like to point out one or two sections which are, I think, of considerable interest to our question.

Section 7 makes it clear that every instrument under which any Crown minerals are held is subject to the Act and to any regulation made from time to time or at any time under the authority of the Act and the provisions of the Act, and those regulations are as binding upon the holder of the rights as though they had been contained in his lease, license or whatever he has. We are, I think, particularly concerned for the purposes of this discussion with oil and gas rights which may be acquired and held from the provincial Crown. To my mind the two most important types of instruments under which rights may be held are petroleum and natural gas reservations and petroleum and natural gas leases.

Petroleum and natural gas reservations do not, of course, grant any interest in the land to which they apply. They are nothing but a tight of exploration with something in the nature of an option by which the holder may, upon performing certain exploratory operations, be entitled to acquire petroleum and natural gas leases of the reservation lands to a limited extent. The reservations are by express prohibition unassignable but the regulations provide that nothing shall prevent the holder from having someone else to do his work for him. It may, I think, be said with confidence that there are many reservations issued in the names of persons who neither had any intention nor the means with which to conduct exploratory operations. They were, however, able to induce others to conduct the work and by the execution of appropriate documents the lands covered by the reservation have been explored, the regulations complied with and leases acquired as a result of it. Be that as it may, there is not provision for assignment and consequently the problems of ownership and transfer of permittee rights are perhaps not too important for our purposes.

With respect to leases, however, many different considerations apply. Because the traffic in provincial oil and gas leases is rather considerable and the variety of "deals" that are made are complicated and numerous enough to stagger the imagination, it would seem desirable to have some convenient and safe method of registering the rights originally acquired and the changes subsequently made with respect to them. At the present time, the assignment of 
rights under Crown oil and gas leases is dealt with under two sections of the Mines and Minerals Act, sections 288 and 289.

Section 288 provides that the Minister shall keep books for registering assignments of "agreements"; and agreements by definition means any lease license, reservation, permit or other agreement made or entered into under the Mines and Minerals Act, the Provincial Lands Act or the Dominion Lands Act.

It is then provided that, subject to the Act and regulations, where an agreement is assignable, an assignment of it may be registered with the Minister. The Minister is entitled to refuse registration unless the assignment is unconditional, proof of execution is satisfactory and its form is satisfactory.

The Minister may refuse to register an assignment in which there are more than four persons shown as assignees.

And then the most important provision of section 288 is subsection (5) to the effect that an assignment registered under the part shall be valid against and prior to any unregistered assignment or subsequently registered assignment. And that is the subsection that establishes priority under the system of registration of assignments.

Section 289 then begins by saying:

"For the purpose of removing doubt it is hereby declared that" and then goes on to provide that a lessee may assign an agreement to himself and another person or persons and upon the registration of the assignment the lessee is entitled to the interest which the assignment purports to convey to him to the same extent as if he were not the assignor; and (b) provides that two or more persons being the lessees under a lease may assign the lease to one or more of them, and upon registration the assignee or assignees are entitled to the interest which the assignment purports to convey to him or them to the same extent as if he or they were not the assignors.

Now there you have the applicable provisions of the Mines and Minerals Act. I might describe briefly the mechanics of issuing leases and handling assignments. Leases are issued by the province in duplicate and are executed first by the lessee and then by the province, with a duplicate executed copy being sent to the lessee. Upon assignment the instrument of assignment, together with the lessee's copy of the lease, must be forwarded to the Department where, if consent is given, the assignment is recorded and each copy of the lease endorsed with a note of the assignment. The lessee's copy of the lease is then returned to him together with a registered copy of the assignment if the lessee sent the assignment in duplicate. For some purposes or perhaps for most purposes the system used by the Crown works quite as well because in the normal, simple, straightforward purchase of a lease there is not much that can be complicated; and if the intended vendor is shown by his copy of the lease and the record at Edmonton to be the registered holder of the lease, then not too much can go wrong, barring notices from unregistered assignees and so forth.

Problems do arise where the interest of the lessee under an oil and gas lease from the Crown is divided among a great many people. If these rights were held under some more elaborate system of registration, probably the documents 
reflecting the true ownership or ownerships could be filed and registered. The Crown, however, will not permit the filing of any documents except the unconditional assignments to which $I$ have referted, and because they are not bound to accept an assignment to more than four assignees the deals by which interests under a Crown lease are split inco many small incerests do noc reach the register in Edmonton but are instead dealt with under an instrument of trust.

There is similarity between the normal oil and gas lease of freehold and the Crown land situation in this respect. Under most frechold oil and gas leases, the lessee is not bound to recognize anything but an absolute assignment of the lessor's entire interest but it has been the practice since Turner Valley days to use instruments of trust to divide the landowner's royalty. This has worked, I think, by and large, very successfully. The same method of dealing with Crown oil and gas rights also works successfully although, of course, many people find it annoying that they are not entitled to deal with what they call their "rights" as freely and without encumbrance as they think they should. Is the convenience of people who wish to deal with oil and gas rights upon a more or less free basis sufficient justification for putting all Crown mines and minerals under some kind of a registration system, be it the old registry system ot the Torrens System? There are many who, I'm sure, will say that it is not.

The Chatrman: The panel in discussing this matter previously have not reached any specific agreement as to the best way of correcting the faults. Mr. Steer, would you sum up some of the recommendations or conclusions reached by the panel?

\section{RECOMMENDATIONS}

This panel has come out for a Torrens System because of the obvious advantages mentioned in the introduction to this panel. If we are to have a Torrens 'System, then we ought, as far as possible, to climinate the exceptions to indefeasibility of a Certificate of Title.

In all statutes except those of Alberta and Saskatchewan, and the old Northwest Territories Real Property Act, the bona fide purchaser is protected from misdescription.

The first suggestion, therefore, is that misdescription be removed from the Act.

It is not thought that it is possible to remove the exception of prior certificate of title. The difficulty of this exception could, however, be minimized if a separate register for minerals was set up.

This suggestion of a separate register would help solve one serious problem with which we are faced, namely, what to do about the numerous cases in which errors have been made in the chain of title to minerals.

If a separate register were set up, then as title holders dealt with their minerals, the new title for the minerals could be issued in the separate register. In cases where errors have been made, the matter could be referred to the court 
and all interested parties heard and the ownership determined. This practice is in fact that used by the Land Titles Office at the present time. We would then have a set of mineral titles which we knew were correct as at a certain date and, all parties having full knowledge of the importance of mines and minerals, it is doubtful if mistakes would easily be made.

\section{DISCUSSION}

During the brief adjournment, I was accused of being too charitable to the limitation sections of the Alberta statute. I wish now to redeem myself.

It would be difficult to estimate the amount of money which surface owners have paid into the assurance fund since it was established. Judging from the reported cases of payments out of the fund, however, it is safe to say that the receipts have been so much in excess of payments that the assurance fee has long since become merely a tax on the transfer of land. I have no certain information but would think that it is fair to say that the contributions to the assurance fund in any month since the war exceeded the cotal of payments out of the fund since Alberta became a province half a century ago.

Until the assurance fund is removed from the provincial tax system it is difficult to see how there can be any major reform in our land registration system. The assurance fund is so fundamental a part of that system that its diversion into the provincial revenue amounts to destruction of the protective system intended by the statute.

It can be argued that mineral owners, and particularly the holders of petroleum leases, have no grievance because complete access to the fund is denied them. Mineral interests are almost invariably registered by way of Caveat and no contribution is made to the fund. If there is a possibility of a multimillion-dollar attack on the assurance fund, the surface owners who alone have contributed to it could, with some justification, ask that mineral owners also contribute. Thus if the oil industry wants an assurance fund it must reconcile itself to paying for it.

One of the problems ahead of the committee is to determine how the insurance fund levy should be made against mineral owners. A mineral which is valueless or even unknown today may be worth substantial sums in the future. In the Turta case, Anton Turta swore on oath that at the time the land was transferred to him he gave no thought to the minerals and placed no value upon them. It is fair to say that the C.P.R. gave them little more thought than did Turta.

During the meetings of the panel during the last week or two, this problem was discussed and I suggested that the mineral owner be free to declare the value which he places upon minerals and to pay a premium in accordance with the declared value. The suggestion came under violent attack from my friends in the oil business. They took the view that they did not wish the world to know what value their companies placed on a given parcel of mineral rights; so for the moment I have no answer to the question, but would say that it will be one of the major problems facing the committee which has been appointed. 
During the intermission, the panel was handed a copy of a stamp which is used to cancel Certificates of Title in the Land Titles Office, Edmonton. The form is as follows:

THIS CERTIFICATE OF TITLE IS CANCELLED

IN ACCORDANCE WITH THE TRANSFER SUBJECT TO ANY EXCEPTIONS AND/OR RESERVATIONS THEREIN, AND A NEW CERTIFICATE OF TITLE NO.

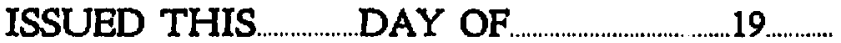
TO

DB

AD REGISTRAR

It is the unanimous decision of all members that there is nothing in the Act which gives the Registrar power to use such a stamp. The Certificate of Title is supposed to speak for itself and, in a general way, not refer to the transfer creating it. The transfer would merge in the Title. In our view the stamp should not be accepted without legislative approval; in its present form it lacks authority for its use.

INDEFEASIBILITY FOOTNOTES

1[1954] S.C.R. 427, 12 W.W.R. (N.S.) 97.

${ }^{2}(1952), 5$ W.W.R. (N.S.) 529, at p. 583.

s(1953), 8 W.W.R. (N.S.) 609, at p. 626.

1 (1905), at p. 29.

LAYCRAFT FOOTNOTES

CAVEAT FOOTNOTES

1(1954), 12 W.W.R. (N.S.) 177.

IIbid., at p. 180.

'11954] S.C.R. 321.

HIEBERT FOOTNOTES

2R.S.M., 1913, c. 171

31887 (Man.) c. 21.

The Public Lands Act, 1949 (Alta.) c. 81, s. 5. 
1R.S.C., 1952, c. 234.

\section{RAILWAY ACT FOOTNOTES}

2[1912] A.C. 333, at p. 342.

[1930] A.C. 111.

Ibid., at p. 118.

SR.S.A., 1942, c. 207.

\section{HISTORICAL SEARCH FOOTNOTES}

'The Alberta Natural Resources Act, 1930 (Can.) c. 71.

2The Soldier Settlement Act, 1919 (Can.) c. 71.

81953 (Alta.) c. 75.

11905 (Can.) c. 3, 3. 21.

\section{CROWN LANDS FOOTNOTES}

${ }^{2}$ The Saskatchewan and Alberta Roads Act, (Can.) c. 38.

sThe Saskatchewan and Alberta Roads Act, 1906 (Can.) c. 45.

11906 (Alta.) c. 24, s. 126.

'The Statuce Law Amendment Act, 1911, 1911.12 (Alta.) c. 4, s. 15 (26).

-The Alberta Naturnl Resources Act, 1930 (Alta.) c. 21 and Schedule thescto.

11949 (Alta.) c. 66.

81953 (Alta.) c. 75, s. 7.

-The Mines and Minerals Act, supra, note 7, s. 2 (1) (b), as amended by 1950 (Alta.) c. 42, s. 1 (a). 